\title{
Cattle Weight Gains in Relation to Stocking Rate on Rough Fescue Grassland
}

\author{
W.D. WILLMS, S. SMOLIAK, AND G.B. SCHAALJE
}

\section{Abstract}

The effects of 4 stocking rates $(1.2,1.6,2.4$, and $4.8 \mathrm{AUM} / \mathrm{ha})$ on cattle production were examined, over a 35-year period, on a Rough Fescue (Festuca scabrella Torr.) Grassland. Forage productivity was reduced at the higher stocking rates. This resulted in a shortened grazing season in the field stocked at $4.8 \mathrm{AUM} / \mathrm{ha}$. Although individual animals' weights decreased with increased stocking rate, cattle gains per unit area increased. Average daily gain of cows was greatest in May but declined to become a loss in September. Calves showed maximum gains from June to July and never lost weight. Stocking rate affected the relative magnitude of average daily gain as well as the trend over the grazing season.

The native grasslands of western Canada are managed primarily for cattle using a system of continuous grazing. In implementing this system, the major decision is to set the stocking rate that will be used. Financial considerations often dictate a high stocking rate that may eventually result in a reduced carrying capacity of the range. Sustained heavy grazing may reduce the productivity of the grassland by lowering plant vigor and, over many years, by modifying the species composition to a cover dominated by less productive species.

Numerous grazing experiments have been reported (Sarvis 1941, Clarke et al. 1947, Woolfolk and Knapp 1949, Johnson 1953, Peters 1955, Lewis et al. 1956, Launchbaugh 1957, Klipple and Costello 1960, Beetle et al. 1961, Reed and Peterson 1961, Houston and Woodward 1966, Bement 1969, Smoliak 1974) that examine the effects of stocking rate on weight gain. However, none have been reported for the Rough Fescue (Festuca scabrella Torr.) Grasslands found in southwestern Alberta and few experiments have extended beyond the time required for the plant community to reach equilibrium with the grazing regime imposed on it. Consequently, this paper reports on the findings, over a 35-year period, of a study that began in 1949 with the objectives of determining the effects of fixed stocking rates on cattle weight gains over the grazing season, the weight gains of cattle over the grazing season on Rough Fescue Grassland, and the relationship between cattle gains and available forage. The effects of fixed stocking rates on the species composition of the Rough Fescue Grassland are reported in a separate paper (Willms et al. 1985).

\section{Site Description}

The study area was in the foothills of southwestern Alberta, 80 $\mathrm{km}$ northwest of Lethbridge at the Agriculture Canada Research Substation near Stavely. Geologic and climatic conditions were described by Willms et al. (1985).

Rough fescue was the dominant species in the study area and Parry oat grass (Danthonia parryi Scribn.) was co-dominant. Vegetation was representative of the Rough Fescue Association (Moss and Campbell 1947).

Historical grazing of the study area was described by Johnston (1961). The area was moderately stocked for summer grazing with cattle from 1884 to 1908 and with horses from 1908 to 1920 . From 1920 to 1943 , the area was again stocked with cattle for summer grazing. Use was heavy during the 1930's drought. The area was

\footnotetext{
Authors are rangeland ecologists and statistician, respectively, Agriculture Canada Research Station, Lethbridge, Alberta, Canada T1J 4B1.

The authors wish to express their appreciation for the contributions made by $\mathrm{Dr}$. A Johnston to the planning and data collection in this experiment. Technicians S.R. Pisko, T.D. Allen, R.G. Gschaid, and B.W. Kesler assisted with the weighing of cattle and the sampling of vegetation.

Manuscript accepted 9 July 1985
}

used lightly for winter pasture from 1944 to 1949.

\section{Methods}

The study was begun in 1949 and terminated in 1983 . Four fields were fenced to enclose areas of $65,48,32$, and 16 ha and stocked with 13 cows and their calves from approximately mid-May to midNovember. This resulted in 4 stocking rates: light (L), 1.2 AUM/ha; moderate (M), 1.6 AUM/ha; heavy (H), $2.4 \mathrm{AUM} /$ ha; and very heavy $(\mathrm{VH}), 2.5-4.8 \mathrm{AUM} / \mathrm{ha}$. The stocking rate on field VH was $4.8 \mathrm{AUM} /$ ha from 1949 to 1958 but was adjusted yearly after 1959 to avoid animal losses. The cattle were removed from the field when they first lost weight. This resulted in stocking rates that varied from 2.5 to $4.8 \mathrm{AUM} / \mathrm{ha}$ and averaged $3.2 \mathrm{AUM} / \mathrm{ha}$ for the period from 1960 to 1983 . The recommended stocking rate for range in good condition in the area was $1.6 \mathrm{AUM} / \mathrm{ha}$ (Wroe et al. 1981).

Cows and calves were obtained from a nearby rancher. From 1949 to 1978, the cattle used were Hereford, Angus, and Hereford $X$ Angus crosses with Hereford being dominant. From 1979 to 1983, the cattle also included Simmental, Charolais, and their crosses with Hereford.

The cattle were introduced into the experimental area in early May of each year. In mid-May they were weighed and partitioned into 4 groups of equal numbers. One group was randomly assigned to each of the $\mathbf{4}$ fields for the duration of the grazing season.

All cattle were weighed at monthly intervals. Food and water were withheld from the animals 1 day prior to weighing. Cows were weighed individually but calves were weighed in lots of 2 to 5 animals within a grazing group. Weighing calves in groups reduced errors since the scale was not accurate for small weights.

Water was provided from dugouts fed by springs and run-off. Cobalt salt and mineral blocks were made available ad libitum to cattle in all fields.

Available forage was estimated by harvesting 10 to 30 plots that had been protected by temporary exclosures within each field. A paired grazed plot was harvested near each exclosure to provide estimates of residual forage and to enable estimates of utilization by subtracting residual from available forage. Estimates of residual forage were made from 1967 to 1981 but available forage was estimated from 1972 to 1981 . Plot area ranged from 0.5 to $1.6 \mathrm{~m}^{2}$. Forage was harvested, near ground level, in early October to avoid snowfall.

Cattle weight gains were analyzed separately for cows and calves. Average daily gains (ADG) were calculated for each interval between weighings (periods (P) 1 to 6: P1, 15 May to $14 \mathrm{June}$; P2, 15 June to 14 July; P3, 15 July to 14 August; P4, 15 August to 14 September, P5, 15 September to 14 October; P6, 15 October to 14 November).

Orthogonal polynomials were used in 2 different ways in the analysis of these data. Since ADG's for all periods in a grazing season formed a set of repeated measurements from each animal, the trend of ADG change over the grazing season was investigated by calculating linear and quadratic polynomial contrasts of ADG over periods for each cow (or group of calves) and applying analysis of variance to these contrasts as in Rowell and Walters (1976). To investigate the effects of stocking rates on the ADG trends of the animals, stocking rate was used as a factor in the analysis of variance and sums of squares of the contrasts due to stocking rates (logarithmic scale) were partitioned into orthogonal polynomial 
Table 1. Available forage and utilization (estimated in October) from 1972-81 and residual forage after grazing from 1967-81 in fields stocked at four rates.

\begin{tabular}{|c|c|c|c|c|c|c|}
\hline & \multicolumn{4}{|c|}{ Stocking Rate } & \multirow[b]{2}{*}{ SEM } & \multirow{2}{*}{$\begin{array}{c}\text { Effect of } \\
\text { stocking rate }\end{array}$} \\
\hline & $\mathbf{L}$ & $\mathbf{M}$ & $\mathbf{H}$ & VH & & \\
\hline $\begin{array}{c}\text { Available forage } \\
(\mathrm{kg} / \mathrm{ha})\end{array}$ & 2199 & 2171 & 1865 & 1170 & 93 & $*$ \\
\hline Utilization (\%) & 26 & 36 & 47 & 81 & 4 & $*$ \\
\hline $\begin{array}{l}\text { Residual forage } \\
\text { (kg/ha) }\end{array}$ & 1748 & 1557 & 1102 & 280 & 64 & $*$ \\
\hline
\end{tabular}

*Significant $(P<0.05)$.

components (Steel and Torrie 1980). These tests were performed (1) to evaluate the signifiance of the ADG-time period contrasts averaged over the stocking rates, and (2) to assess trends in the ADG-time period contrasts due to stocking rates.

Analysis of variance was also used to test: the effects of stocking rate on individual ADG's for each period; cattle weights prior to the grazing season; total changes in cattle weights over the grazing season; and estimates of forage yield and percent utilization. In all analyses of variance, the two-way model without interaction was used, with years and stocking rates as the main effects. The validity of the analysis depends on the assumptions that the years were independent of each other and that the geographical effects confounded with the stocking rates were negligible.

Forage production was correlated with stocking rate and precipitation, for the period preceding and during the growing season representing the winter period (November to March) and individual months from April to August, using a stepwise regression procedure that maximized $R^{2}$ (SAS Institute Inc. 1982).

Several methods were then used to relate weight gain of cattle to available forage. One method was to determine available forage per animal unit (AF/AU). This estimate was related to weight gain of cows and calves using several models including the polynomial and plateau. However, the best fit was obtained with an asymptotic model using the Mitscherlich equation (Mitscherlich 1930 in Mead and Pike 1975): $Y=M\left(1-\mathrm{e}^{A-B X}\right)$, where $M$ is the asymptote, $A$ is the $Y$-intercept (set at zero), B is the rate coefficient, and $X(\mathrm{~kg})$ is the AF/AU. The dependent variable was, in different analyses, net wet gain $(\mathrm{kg})$ in cows, net weight gain $(\mathrm{kg})$ in calves, and maximum weight gain ( $\mathrm{kg}$ ) in cows. The best fit (asymptote and rate coefficient) was obtained by iteration (SAS Institute Inc. 1982). Data from all fields were included in this analysis. Correlations were also made of net and maximum weight gains on total available forage in each field.

In other analyses, $A D G$ in the final grazing period was related to residual forage, measured in that period, using linear and quadratic polynomial equations. This approach assumed a relationship between residual forage and grazing pressure and eliminated forage quality as a factor influencing weight gain. Data for this analysis were available from 1967 to 1981 and the analysis was repeated with and without the data from field $\mathrm{VH}$.

\section{Results}

Available forage was similar at the 2 lowest stocking rates over the years in which they were measured (Table 1). Availability declined substantially as stocking rate was increased. Forage utilization in October ranged from $26 \%$ in field $\mathrm{L}$ to $81 \%$ in field VH (Table 1). When utilization was extrapolated to the end of the grazing season, on the basis of average daily use prior to harvesting, then the estimates for fields $\mathrm{L}, \mathrm{M}, \mathrm{H}$, and $\mathrm{VH}$ were $28,41,53$, and $84 \%$, respectively. Residual forage in October was $1,748 \mathrm{~kg} / \mathrm{ha}$ in field $L$ and $280 \mathrm{~kg}$ / ha in field VH (Table 1).

Cattle weights at the start of the grazing season were similar in each field (Table 2). Total individual weight gains over the grazing season declined significantly $(P<0.05)$ with increased stocking rate, (Table 2). However, weight gains per unit area increased with an increase in stocking rate. Cattle gains per hectare over the
Table 2. Initial cattle weights (kg) at the beginning of the grazing season and weight gains (kg) over a six-month grazing period, from 1949 to 1983 , in fields stocked at four rates.

\begin{tabular}{cccccc}
\hline \hline & \multicolumn{2}{c}{ Initial weights } & & \multicolumn{2}{c}{ Weight gains } \\
\cline { 2 - 3 } \cline { 5 - 6 } Stocking rate & Cows & Calves & & Cows & Calves \\
\hline L & 409.8 & 63.4 & & 85.5 & 138.4 \\
M & 419.1 & 64.2 & & 85.4 & 144.7 \\
H & 415.2 & 62.7 & & 67.5 & 137.1 \\
VH' & 421.2 & 61.7 & & 61.1 & 102.9 \\
Standard error of mean & 8.1 & 6.0 & & 15.8 & 13.1 \\
Effect of & & & & & \\
stocking rate & & & & $*$ \\
Overall & NS & NS & & $*$ \\
Linear & & & & $*$ & $*$ \\
Quadratic & & & NS & $*$ \\
\hline
\end{tabular}

'Length of grazing season in field VH adjusted annually, after 1959, in relation to available forage.

${ }^{2}$ Effect of stocking rate on the relationship of weight gain to stocking rate is not significant $(P>0.05)$.

"Effect of stocking rate on the relationship of weight gain to stocking rate is significant $(P<0.05)$.

grazing season were $17,23,27$, and $49 \mathrm{~kg}$ for cows, and $28,39,55$, and $83 \mathrm{~kg}$ for calves in fields $\mathrm{L}, \mathrm{M}, \mathrm{H}$, and $\mathrm{VH}$, respectively.

The weight gains of cows declined linearly with an increase in stocking rate when measured as total gain or as $A D G$ within a period (Table 3 ). Only in period 2 was the effect not noticeable.

Table 3. Effect of stocking rate on ADG ( $\mathrm{kg} /$ animal) during individual periods throughout the graxing season.

\begin{tabular}{lccccc}
\hline \hline $\begin{array}{c}\text { Cattle } \\
\text { type }\end{array}$ & Period & ADG & SEM & $\begin{array}{c}\text { Relationship of ADG } \\
\text { to stocking rate }\end{array}$ \\
\hline \multirow{4}{*}{ Cows } & 1 & & & Linear & Quadratic \\
\cline { 5 - 5 } & 2 & 0.91 & 0.21 & $*$ & NS \\
& 3 & 0.95 & 0.14 & NS & NS \\
& 4 & 0.50 & 0.14 & $*$ & NS \\
& 5 & -0.11 & 0.17 & $*$ & NS \\
Calves & 6 & -0.64 & 0.21 & $*$ & NS \\
& 1 & 0.82 & 0.12 & NS & NS \\
& 2 & 0.82 & 0.08 & NS & $*$ \\
& 3 & 0.95 & 0.11 & $*$ & NS \\
& 4 & 1.00 & 0.16 & NS & $*$ \\
& 5 & 0.73 & 0.12 & $*$ & NS \\
& 6 & 0.41 & 0.18 & $*$ & NS \\
\hline
\end{tabular}

'Linear or quadratic regression coefficients are not significantly $(P>0.05)$ different from zero.

* Linear or quadratic regression coefficients are significantly $(P<0.05)$ different from zero.

The ADG of cows declined over the grazing season and became negative in period 5 (Fig. 1). ADG increased from periods 1 to 2 only in fields $\mathrm{H}$ and $\mathrm{VH}$. The ranking of stocking rates was generally maintained throughout the grazing season (Fig. 1). However, the relationship between linear contrasts of $A D G$ over time and stocking rates was linear (Table 4), indicating divergence of ADG's toward the end of the season. 


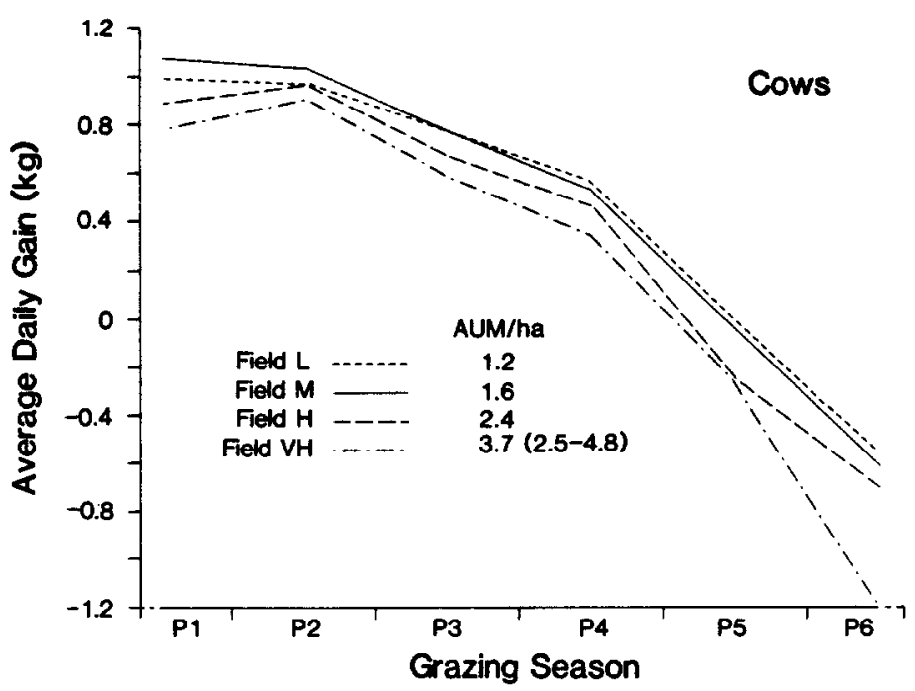

Fig. 1. Average daily gain of cows in relation to stocking rate over the grazing season (PI, 15 May to 14 June; P2, 15 June to 14 July; P3, $15 \mathrm{July}$ to 14 Aug.; P4, 15 Aug. to 14 Sept.; P5, Sept. to 14 Oct.; P6, 15 Oct. to 14 Nov.).

Table 4. A test of the average trend of ADG over time and of the effect of stocking rate on the trend (demonstrated in Figures 1 and 2).

\begin{tabular}{|c|c|c|c|c|}
\hline \multirow[b]{2}{*}{ Cattle type } & \multirow{2}{*}{$\begin{array}{c}\text { Trend of ADG } \\
\text { over time }\end{array}$} & \multirow{2}{*}{$\begin{array}{l}\text { Significance } \\
\text { of trend }\end{array}$} & \multicolumn{2}{|c|}{$\begin{array}{l}\text { Significance of effect of } \\
\text { stocking rate on trend }\end{array}$} \\
\hline & & & Linear & Quadratic \\
\hline Cows & $\begin{array}{c}\text { Linear } \\
\text { Quadratic }\end{array}$ & * & * & $\begin{array}{l}\text { NS }^{2} \\
\text { NS }\end{array}$ \\
\hline Calves & $\begin{array}{c}\text { Linear } \\
\text { Quadratic }\end{array}$ & * & NS & $\begin{array}{l}\text { NS } \\
\text { NS }\end{array}$ \\
\hline
\end{tabular}

'A test for parallelism in trends among stocking rates.

2The effect of stocking rate on the trend is not significant $(P>0.05)$.

*The trend or the effect of stocking rate on the trend is significant $(P<0.05)$.

Stocking rate had a significant $(P<0.05)$ effect on the weight gain of calves over the grazing season (Table 2). Calf weight gains increased as stocking rates increased from fields $L$ to $M$ but then declined with further increase in stocking rates. This relationship was evident from the quadratic trend of ADG's over stocking rates which was significant $(P<0.05)$ over the whole grazing season (Table 2) and in periods 2 and 4 of the grazing season (Table 3 ).

In spite of significant trends, however, the ADG's of calves for all stocking rates were similar during the first half of the grazing season (Fig. 2) and the rankings of the stocking rates were inconsistent. However, from periods 4 to 6 , the rankings were more consistent and the differences were greater. The ADG in field VH was smallest during this time. As in the cow data, the linear contrasts for ADG of calves over time showed a significant linear trend (Table 4) over stocking rates, indicating a gradual divergence in ADG between stocking rates. The ADG of calves was maximum in periods 3 or 4 and never became negative (Fig. 2).

The ADG's in periods 5 and 6, of field VH, could be determined in each year before 1960 but only for those years when grazing was continued after 1959, because of the policy of removing animals in the summer when they began losing weight. As such, the ADG of periods 5 and 6 does not consider the weight loss as a function of limited forage and is probably too high.

Forage production (FP, $\mathrm{kg} / \mathrm{ha}$ ) was best correlated in a 4variable equation with stocking rate (SR, $\mathrm{AUM} / \mathrm{ha}$ ) and precipitation (mm) in May (MY), June (JE), and July (JY): FP $=-170-25.8$ $\mathrm{SR}+12.7 \mathrm{MY}+13.2 \mathrm{JE}+10.0 \mathrm{JY}\left(R^{2}=0.84, P<0.01\right.$ for each

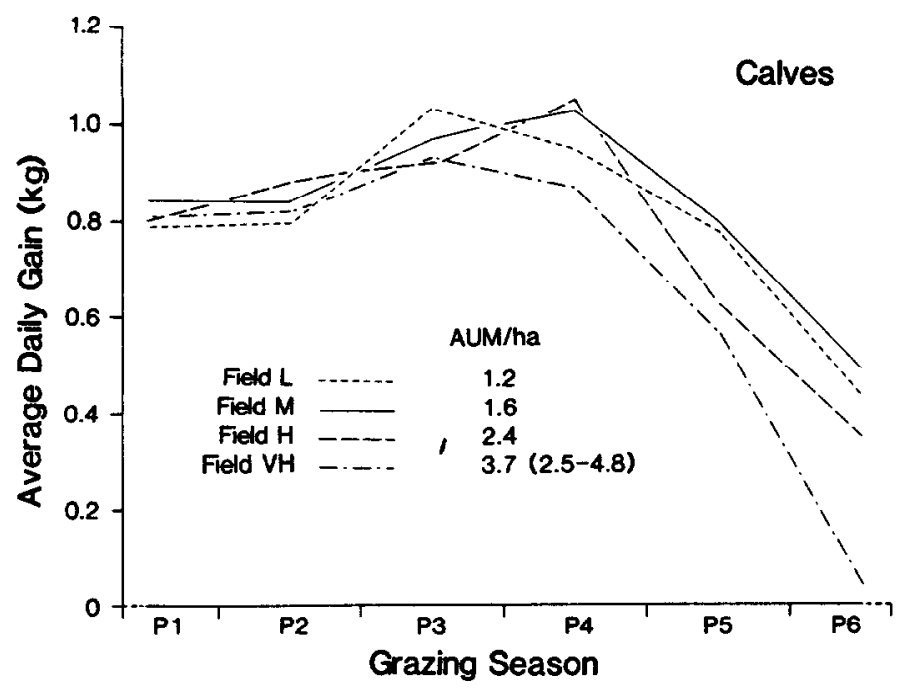

Fig. 2. Average daily gain of calves in relation to stocking rate over the grazing season (P1, 15 May to 14 June; P2, 15 June to 14 July; P3, 15 July to 14 Aug.; P4, 15 Aug. 1014 Sept.; P5, 15 Sept. to 14 Oct.; P6, 15 Oct. to 14 Nov.).

variable). Precipitation in April was negatively correlated while precipitation in winter had no effect $(P>0.05)$.

The asymptote of weight gain was $151.5 \mathrm{~kg}$ for calves and 111.5 $\mathrm{kg}$ for cows (Fig. 3). Ninety-nine percent of these weights were achieved with 5,000 and $6,000 \mathrm{~kg}$ forage, per $\mathrm{AU}$, for calves and cows, respectively. Unit forage weights in the data set ranged from 700 to $16,000 \mathrm{~kg}$.



Fig. 3. The relationship of weight gain (Y) over the grazing season to unit available forage $(A F / A U, X)$ on fields stocked at 4 rates.

Average daily gains of cows and calves in the final 2 periods of the grazing season were not related to residual forage which varied from 600 to $2,400 \mathrm{~kg} /$ ha in fields $\mathrm{L}, \mathrm{M}$, and $\mathrm{H}$. Neither the linear nor quadratic polynomial equations were significant $(P>0.10)$. The inclusion of ADG obtained in the last grazing period, from field $\mathrm{VH}$, did not improve the regression even though the estimate of residual forage extended the range to near zero.

Cow weight gains, both net $(\mathrm{CWn})$ and maximum $(\mathrm{CWm})$, were significantly $(P<0.05)$ correlated with total available forage $(\mathrm{AF}$, $\mathrm{kg} / \mathrm{ha})$ only in field VH: CWn $=22.8+0.036 \mathrm{AF}\left(R^{2}=0.9, \mathrm{n}=8\right)$; $\mathrm{CWm}=36.1+0.032 \mathrm{AF}\left(R^{2}=0.6, \mathrm{n}=8\right) ; \mathrm{CWm}=36.1+0.032 \mathrm{AF}$ $\left(R^{2}=0.6, n=9\right)$. Calf weight gains in any field were not significantly $(P>0.05)$ correlated with total available forage. 
Table 5. Predicted forage yields, forage requirements, and calf gains in relation to set stocking rates over the long term and short term (nested in the former) calculated for $1 \mathrm{ha}$.

Short-term effects at set stocking rates

Long-term effects at set stocking rates

\begin{tabular}{|c|c|c|c|c|c|c|c|c|}
\hline \multicolumn{2}{|c|}{ Stocking rate } & \multicolumn{2}{|c|}{ Forage (kg) } & \multirow{2}{*}{$\begin{array}{c}\text { Available } \\
\text { forage }(\mathrm{kg})^{4}\end{array}$} & \multirow{2}{*}{$\begin{array}{c}\text { Stocking rate } \\
\text { AUM }\end{array}$} & \multirow{2}{*}{$\begin{array}{c}\text { Forage required } \\
\text { DR }\end{array}$} & \multicolumn{2}{|c|}{ Animal gain (kg) } \\
\hline AUM & $\mathbf{A} \mathbf{U}^{\mathrm{I}}$ & $\mathrm{MIG}^{2}$ & $\mathrm{DR}^{3}$ & & & & Individual $^{5}$ & Area \\
\hline 1.2 & 0.20 & 1000 & 396 & $2000^{6}$ & $\begin{array}{l}1.2 \\
2.4 \\
4.8\end{array}$ & $\begin{array}{r}396 \\
792 \\
1584\end{array}$ & $\begin{array}{l}152 \\
152 \\
135\end{array}$ & $\begin{array}{r}30 \\
61 \\
108\end{array}$ \\
\hline 1.6 & 0.27 & 1350 & 534 & $1886^{6}$ & $\begin{array}{l}1.2 \\
2.4 \\
4.8\end{array}$ & $\begin{array}{r}396 \\
792 \\
1584\end{array}$ & $\begin{array}{l}152 \\
149 \\
132\end{array}$ & $\begin{array}{r}30 \\
60 \\
106\end{array}$ \\
\hline 2.4 & 0.40 & 2000 & 792 & $1658^{6}$ & $\begin{array}{l}1.2 \\
2.4 \\
4.8\end{array}$ & $\begin{array}{r}396 \\
792 \\
1584\end{array}$ & $\begin{array}{l}151 \\
149 \\
132\end{array}$ & $\begin{array}{r}30 \\
60 \\
106\end{array}$ \\
\hline 4.8 & 0.80 & 4000 & 1584 & $974^{7}$ & $\begin{array}{l}1.2 \\
2.4 \\
4.8\end{array}$ & $\begin{array}{r}396 \\
792 \\
1584\end{array}$ & $\begin{array}{l}149 \\
134 \\
100\end{array}$ & $\begin{array}{l}30 \\
53 \\
80\end{array}$ \\
\hline
\end{tabular}

16-month grazing period.

${ }^{2}$ Maximum individual gain based on $5,000 \mathrm{~kg} / \mathrm{AU}$ (Fig. 3).

${ }^{3}$ Daily requirement based on $11 \mathrm{~kg} /$ day/AU.

${ }^{4}$ Relative yield after long-term stocking at fixed rates.

${ }^{3}$ Calculated for calves from Figure 3.

C Capable of supporting 1.2 to $4.8 \mathrm{AUM}$ on short term.

${ }^{7}$ Capable of supporting 1.2 to 2.4 , but not 4.8 , AUM on short term.

\section{Discussion}

Forage production was related to precipitation and past historical use. Productivity may decline, over a short term, because of a loss in plant vigor or, over a long term, because of a change in species composition to one that is less productive. In a study made concurrently on the same area, we found that persistent heavy grazing of Rough Fescue Grassland favored an increase in the proportion of unproductive forbs and grasses and a reduction in the proportion of rough fescue (Willms et al. 1985). The net effect was a decline in range condition and a reduction in the recommended carrying capacity (Wroe et al. 1981).

The equation relating forage production with precipitation and previous stocking rate suggests a decrease in forage of about 258 $\mathrm{kg} / \mathrm{ha}$ for each additional AUM with which the range was stocked. As a variable in a prediction equation, this has little value unless it can be related to the plant community which it represents. For the fescue grassland in this study, the plant communities in fields $L, M$, $\mathrm{H}$, and $\mathrm{VH}$ were, respectively, rough fescue-Parry oat grass, rough fescue-Parry oat grass, Parry oat grass-rough fescue, and Parry oat grass-Idaho fescue (Festuca idahoensis Elmer) (Willms et al. 1985).

July precipitation was most important in determining total forage production in the current year. Lack of response from early spring or winter precipitation suggests that moisture during that time was not limiting in the years for which data were available. In other work, forage production was best correlated with precipitation occurring before August on the Mixed Prairie (Smoliak 1986 and before September in the Mountain Grasslands of western Montana (Mueggler 1983).

The greater cattle gains per unit area on heavily stocked ranges were similar to results reported by others (Sarvis 1941, Clarke et al. 1947, Launchbaugh 1957, Klipple and Costello 1960, Beetle et al. 1961), and seem to indicate that most benefit could be derived from a heavy stocking rate. Bement (1969) suggested that maximum profits could be realized when yields per unit area were near maximum on a short grass prairie. However, in the present study, the grazing season in field $\mathrm{VH}$ was shortened by about 57 days after 1959. The loss of flexibility in grazing management, the cost of additional feed to the end of the grazing season, and the condition of the animals at market are only 3 of many factors to be considered when assessing the benefits of producing maximum gains per unit area.
Only field $M$ was stocked at the recommended carrying capacity of $1.6 \mathrm{AUM} /$ ha (Wroe et al. 1981) for range in good condition. Field $\mathrm{L}$ was understocked while fields $\mathrm{H}$ and $\mathrm{VH}$ were overstocked. Despite a loss in forage productivity, field $\mathrm{H}$ was able to support cattle for the entire grazing season in every year of the study.

Field VH supported from 3 to 4 times the recommended carrying capacity in the first 11 years of the study. The subsequent loss in carrying capacity forced the removal of cattle before the end of the grazing season and a reduction of stocking rate from $4.8 \mathrm{AUM} / \mathrm{ha}$ to an average of $3.2 \mathrm{AUM} / \mathrm{ha}$. The revised stocking rate was still about 3.5 times the recommended rate for a grassland in poor condition.

The heaviest stocking rate resulted in a $46 \%$ decrease in forage availability but almost triple the cattle weight gain per unit area. These results were achieved well after the plant communities had adjusted to the grazing influence but at the cost of early removal of cattle. Keeping the animals in field VH for the same length of time as in the other fields would have resulted in considerable loss of cattle gains and a further decrease in forage productivity. It would appear that the readjusted stocking rate of $3.2 \mathrm{AUM} / \mathrm{ha}$, modified yearly in relation to available forage, can be sustained, while stocking at $4.8 \mathrm{AUM} /$ ha could result in complete destruction of range productivity. However, managing for maximum gains on a unit area basis introduces considerable risk which may be untenable to most livestock operations.

Individual animals gained most weight at light or moderate stocking rates (Table 2). The greater ADG of calves in field $M$ than of those in field $L$ was consistent in all periods throughout the grazing season, except in period 3 (Fig. 2). Cows also gained more in field $M$ in periods 1 and 2 . An apparent increase in weight gain, with a small increase in stocking rate, has been reported elsewhere (Peters 1955). Powell et al. (1982) showed that calves on poor range produced better gains than did calves on good range. Evidently, native range in Nebraska that was in good condition offered forage that was less digestible than forage from range in poor condition.

Near maximum individual cattle gains were achieved with 5,000 $\mathrm{kg} \mathrm{AF} / \mathrm{AU}$. Fields $\mathrm{L}, \mathrm{M}, \mathrm{H}$, and $\mathrm{VH}$ produced, on average, 11,000 , $8,100,4,600$, and $1,450 \mathrm{~kg} \mathrm{AF} / \mathrm{AU}$, respectively. This indicates that field $H$ was managed most efficiently since field $L$ and $M$ produced in excess of the required forage while field VH was considerably deficient. Evidently, forage was not limiting towards the end of the 
grazing season in either fields $L, M$, or $H$ since $A D G$ in the final grazing period was not related to residual forage.

The relationships defined in this study may be used to predict available forage and, in turn, the stocking rate for optimum sustained beef production. This may be done by using long-term weather records to determine probable forage yield. This estimate, combined with estimates of weight gain in relation to available forage (Fig. 3) and length of grazing season can be combined to develop an appropriate grazing strategy as illustrated in Table 5. The information, with animal gain calculated for the calf component of the $A U$, shows that range in good condition could support a heavy stocking rate on a short term but, as the range deteriorates, the carrying capacity will also be reduced. This information identifies stocking at $2.4 \mathrm{AUM} /$ ha as the most efficient (of the rates examined) since it was sustained over a long term, it produced near maximum individual gains, and yields per unit area were maximum. The management strategy that may be tempting would be to stock the range heavily for several years before reducing to an acceptable level. This may be possible but at the risk of prolonged loss of forage and cattle production.

Restrictions on nutrient intake were apparent throughout the grazing season in field VH for cows, but only after period 3 for calves (Figs. 1 and 2). Presumably, calves relied primarily on milk in the first 3 periods of the grazing season.

In periods 5 and 6 , cows lost weight while calves reduced their weight gain. Similar results were reported by Launchbaugh (1957) for cows on the shortgrass prairie. Since forage quantity was abundant in fields $L$ and $M$, the weight loss may be attributed to loss of forage digestibility which may lead to a reduction of forage intake (van Soest 1965). Bezeau and Johnston (1962) reported a reduction of about $50 \%$ in the digestibility and nutritive value of native grasses from spring to early summer.

The model used to assess the effect of stocking rate on ADG at various periods throughout the grazing season was similar to that proposed by Hart (1978) (i.e., linear after stocking rate transformed to their logarithms indicating a concave trend above the critical rate) but without the plateau. Evidence for a plateau would be indicated by a significant quadratic polynomial on a test of the transformed stocking rates.

However, the exponential model gave the best fit of total gain to AF/AU. This was identical to the model proposed by Mott (1960) but apparently invalidated by subsequent evidence (Peterson et al. 1965, Jones and Sandland 1974). The exponential model should be the correct one under the management conditions of this study where the animals were removed before losing weight but after having consumed most of available forage. Evidently, the critical stocking rate, the point at which weight gain would decline in relation to forage, occurred between 2.4 and $4.8 \mathrm{AUM} /$ ha but the exact rate varied with productivity in the current year.

Differences between the trends of ADG to stocking rate and animal gain to AF/AU are probably accounted for by the type of data explained and by the variability included. In the first trend, the model describes weight gain over stocking rate with the amongyear variability removed while in the second trend, the model describes weight gain in relation to available forage with the among-year variability included.

Very heavy stocking resulted in a loss of flexibility in managing cattle. The duration that cattle were kept in field $\mathrm{VH}$, in any year, depended on available forage which was related to precipitation during that year. In effect, the forage in field VH was utilized as an annual crop without the benefit of potentially high productivity that such crops offer.

Although an economic and ecological impact assessment was not included in this study, it was evident that stocking at 2.4 AUM/ha (field $\mathrm{H}$ ) produced satisfactory yields without loss of management flexibility when beef production was the only resource being managed. However, stocking at this rate resulted in a substantial reduction in the cover of rough fescue and an increase in the cover of shorter, less productive, grasses. Therefore, a stocking rate of approximately $1.6 \mathrm{AUM} /$ ha should be used to maintain a productive vegetative resource as well as to sustain a habitat for wildlife in the Rough Fescue Grassland zone.

\section{Literature Cited}

Beetle, A.A., W.M. Johnson, R.L. Lang, M. May, and D.R. Smith. 1961. Effect of grazing intensity on cattle weights and vegetation of the Bighorn experimental pastures. Univ. of Wyoming Agr. Exp. Sta. Bull.

Bement, R.E. 1969. A stocking-rate guide for beef production on bluegrama range. J. Range Manage. 22:83-86.

Bezeau, L.M., and A. Johnston. 1962. In vitro digestibility of range forage plants of the Festuca scabrella association. Can. J. Plant Sci. 42:692-697.

Clarke, S.E., E.W. Tisdale, and N.A. Skoglund. 1947. The effects of climate and grazing practices on short-grass prairie vegetation in southern Alberta and southwestern Saskatchewan. Can. Dep. Agr. Tech. Bull. 46.

Hart, R.H. 1978. Stocking rate theory and its application to grazing on rangelands. p. 547-550. In: Proc. 1st Int. Rangeland Cong.

Houston, W.R., and R.R. Woodward. 1966. Effects of stocking rates on range vegetation and beef cattle production in the Northern Great Plains. USDA Tech. Bull.

Johnston, A. 1961. Comparison of lightly grazed and ungrazed range in the fescue grassland of southwestern Alberta. Can. J. Plant Sci. 41:615-622.

Johnson, W.M. 1953. Effect of grazing intensity upon vegetation and cattle gains on ponderosa pine-bunchgrass ranges of the front range of Colorado. USDA Cir. No. 929. U.S. Government Printing Office Washington, D.C.

Jones, R.J., and R.L. Sandland. 1974. The relation between animal gain and stocking rate. Derivation of the relation from the results of grazing trials. J. Agr. Sci. 83:335-342.

Klipple, G.E., and D.F. Costello. 1960. Vegetation and cattle responses to different intensities of grazing on short-grass ranges on the Central Great Plains. Rocky Mt. Forest and Range Exp. Sta., USDA Tech. Bull. 1216.

Launchbaugh, J.L. 1957. The effect of stocking rate on cattle gains and on native shortgrass vegetation in west-central Kansas. Kansas Agr. Exp. Sta. Bull. 394.

Lewis, J.K., G.M. van Dyne, L.R. Albee, and F.W. Whetzal. 1956. Intensity of grazing-Its effect on livestock forage production. South Dakota Agr. Exp. Sta. Bull. 459.

Mead, R., and D.J. Pike. 1975. A review of response surface methodology from a biometric viewpoint. Biometrics 31:803-851.

Mitscherlich, E.A. 1930. Die Bostimmung des Dungerbedurfnisses des Bodens. Paul Parey, Berlin.

Moss, E.H., and J.A. Campbell. 1947. The fescue grassland of Alberta. Can. J. Res. C25:209-227.

Mott, G.O. 1960. Grazing pressure and the measurement of pasture production. p. 606-611. In: Proc. 8th Int. Grassland Cong.

Mueggler, W.F. 1983. Variation in production and seasonal development of Mountain Grasslands in Western Montana. USDA Res. Paper INT-316.

Peters, H.F. 1955. Range Experimental Farm, Manyberries, Alberta. Prog. Rep. 1948-1953. Can. Dep. Agr. Exp. Farms Serv.

Peterson, R.G., H.L. Lucas, and G.O. Mott. 1965. Relationship between rate of stocking and per animal and per acre performance on pasture. Agron. J. 57:27-30.

Powell, D.J., D.C. Clanton, and J.T. Nichols. 1982. Effects of range condition on the diet and performance of steers grazing native sandhills range in Nebraska. J. Range Manage. 35:96-99.

Reed, M.J., and R.A. Peterson. 1961. Vegetation, soil, and cattle responses to grazing on northern Great Plains range. USDA Tech. Bull. 1252.

Rowell, J.G., and P.E. Walters. 1976. Analysing data with repeated observations on each experimental unit. J. Agr. Sci., Camb. 87:423-432.

Sarvis, J.T. 1941. Grazing investigations on the Northern Great Plains. Agr. Exp. Sta., N. Dak. Agr. College, USDA Bull. 308.

Smoliak, S. 1974. Range vegetation and sheep production at three stocking rates on Stipa-Bouteloua prairie. J. Range Manage. 27:23-26.

Smoliak, S. 1986. Influence of climatic conditions on production of StipaBouteloua Prairie over a 50-year period. J. Range Manage. 39:100-102.

SAS Institute Inc. 1982. SAS User's Guide: Statistics. 1982 Edition. Cary, N.C.

Steel, R.G.D., and J.H. Torrie. 1980. Principles and procedures of statistics. Biometrical Approach. 2nd ed. McGraw-Hill Book Co., Toronto. 
van Soest, P.J. 1965. Symposium on factors influencing the voluntary intake of herbage by ruminants: voluntary intake in relation to chemical composition and digestibility. J. Anim. Sci. 24:834-843.

Willms, W.D., S. Smoliak, and J.F. Dorman. 1985. Effects of stocking rate on a rough fescue grassland vegetation. J. Range Manage. 38:220-225.
Woolfolk, E.J., and B. Knapp, Jr. 1949. Weight and gain of range calves as affected by rate of stocking. Mont. State Coll. Agr. Exp. Sta. Bull. 463. Wroe, R.A., S. Smoliak, M.G. Turnbull, and A. Johnston. 1981. Guide to range condition and stocking rates for Alberta. 1981. Alberta Energy and Nat. Res., Edmonton. 